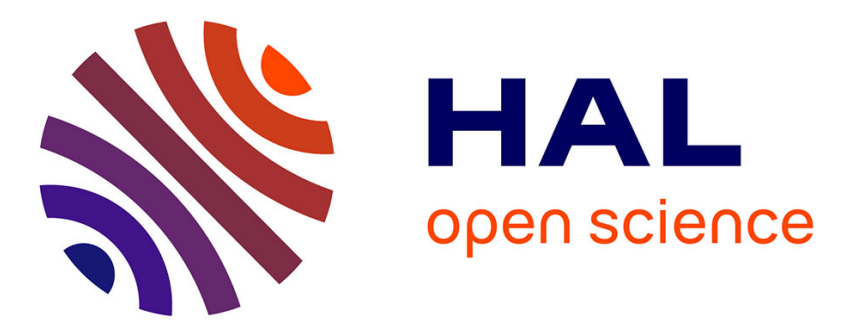

\title{
Debate: Developmental and integrative approaches in child and adolescent psychiatry inpatient facilities: the case of a tertiary university hospital in Paris
}

David Cohen, Cyril Hanin, Xavier Benarous

\section{- To cite this version:}

David Cohen, Cyril Hanin, Xavier Benarous. Debate: Developmental and integrative approaches in child and adolescent psychiatry inpatient facilities: the case of a tertiary university hospital in Paris. Child and Adolescent Mental Health, 2021, 10.1111/camh.12461 . hal-03187447

\section{HAL Id: hal-03187447 https: / hal.sorbonne-universite.fr/hal-03187447}

Submitted on 1 Apr 2021

HAL is a multi-disciplinary open access archive for the deposit and dissemination of scientific research documents, whether they are published or not. The documents may come from teaching and research institutions in France or abroad, or from public or private research centers.
L'archive ouverte pluridisciplinaire HAL, est destinée au dépôt et à la diffusion de documents scientifiques de niveau recherche, publiés ou non, émanant des établissements d'enseignement et de recherche français ou étrangers, des laboratoires publics ou privés. 
Journal: Child and Adolescent Mental Health

Editors: Gabrielle Carlson, Rachel Elvins

Theme: Wat should a useful child or adolescent inpatient unit look like and under what circumstances should they be utilized?

Deadline: March, 1, 2021 (publication in May)

Word length: 1140 words

Developmental and integrative approaches in child and adolescent psychiatry inpatient facilities: the case of a tertiary university hospital in Paris

David Cohen $^{1,2}$, Cyril Hanin ${ }^{1}$, Xavier Benarous ${ }^{3,4}$

${ }^{1}$ Department of Child and Adolescent Psychiatry, GH Pitié-Salpêtrière, APHP, Paris, France
${ }^{2}$ Sorbonne Université, CNRS UMR 7222 Institut des Systèmes Intelligents et Robotiques
${ }^{3}$ Department of Child and Adolescent Psychopathology, Amiens University Hospital, Amiens, France
${ }^{4}$ INSERM Unit U1105 Research Group for Analysis of the Multimodal Cerebral Function, University of Picardy
Jules Verne (UPJV), Amiens, France

Correspondence: david.cohen@aphp.fr

\begin{abstract}
Based on the specific experience of a tertiary university hospital in Paris, France, we propose a theoretical framework encompassing developmental, multidimensional, ecosystemic, and multifactorial perspectives for child and adolescent psychiatry. Consequently, a modern CAPD should be multidisciplinary and implemented in a large medical setting with close disciplines; should promote tailored and integrative treatment; should include some organizational aspects (e.g., tutoring) and should also be opened to cultural and school interventions. Finally, for complex cases, it should keep ambitious goals in terms of both clinical and functional recovery.
\end{abstract}




\section{General information}

The Child and Adolescent Psychiatric Department of the Pitié-Salpêtrière Hospital (CAPD-PS) is a tertiary care university referral center providing care to children and adolescents up to 18 years of age. It is the largest CAPD in the Paris area. It includes six inpatient units (67 beds), three day care hospitals (40 sits) and also provides many outpatient consultations ( $\geq 20,000 /$ year). The service catchment area includes around $12,000,000$ people. The CAPD-PS was founded by Georges Heuyer before World War II. It is located in a hospital that serves mainly adult patients and admission are organized in the context of French free access to care for all.

Other inpatient facilities do exist in Paris area (see details in figure 1, and indications in table 1). Most of them focus on crisis management and are in the public health sector. Some are liaison psychiatry facilitiesin a pediatric department; others are autonomous CAPD inpatients units.Few focus on specific indications (e.g. eating disorders) or ages (e.g. children). Therefore, clinical management remains rather heterogeneous and refers to multiple theoretical approaches to provide a comprehensive and operational model for crisis management. Problematic behaviors may be understood as symptoms of a medical/psychiatric condition (medical model), as maladaptive strategies in a context of vulnerability/adversity (adaptation/developmental model), and finally as a mode of communication in a context of ill-adapted relational patterns (systemic model). We believe that a first line CAPD inpatient unit should be able to combine these models to manage the diversity of clinical acute expressions. This means involving the intervention of professionals from various disciplines and being aware of such different levels of understanding could help to preclude any role confusion and to provide better targeted interventions (Guedj-Bourdiau et al., 2021).

\section{Inpatients units}

The CAPD-PS serves patients with severe treatment-refractory illness, with an average length of stay longer than most CADP hospital settings. Patients are admitted after second- or third-lines of treatment from other inpatient or outpatient services. Based on patient's age and clinical profile, they are admitted to one of the six inpatients facilities. General inpatients facilities encompass three 15-bed units, one for the 6-12-year-old, another for the 12-15-year-old, and a last one for the 15-18-year-old inpatients. Each unit has a certain form of autonomy with specific paramedical team, psychologist, speech therapist, occupational therapist, social worker and doctors (residents, chief resident, and senior psychiatrist). Activities provided involve individual counselling, supportive groups, occupational therapy, school when possible, recreational and sporting activities. The most significant feature of these units compared to others regionally or nationally is the lack of a priori duration of stay and the possibility of extending the length of stay based on patient's benefit. E.g., the mean length of stay is three months in the adolescent wards with, unsurprisingly among these inpatients particularly enriched in resistant form of psychiatric disorders, a high rate of harsh environmental background and untreated mild developmental disabilities (e.g., specific learning disabilities, motor disorder)(Benarous et al., in press). Throughout admission, , an emphasis is put on the family system with weekly family sessions. Inpatients are discharged only when a patient's centered project has been constructed without an a priori duration of stay. The opportunity for the patients to return home on progressive periods of leave help us understand different perspectives involved in 
patients' difficulties and family burden. This is particularly true within contexts of shared insecure affective boundaries within families and difficulties in expressing ambivalent/conflicting views (Aouidad et al., 2020).

A 6-bed intensive psychiatric care unit has a higher professional/inpatients ratio. It serves patients with severe behavioral manifestations (e.g., delirium) sometimes associated with forensic issues, those requiring important nursing (e.g., catatonia) or those with medical comorbid conditions (e.g. treatment refusal with life-threatening risk). The department is a referral center for catatonia, bipolar disorder, early onset schizophrenia and rare medical conditions with psychiatric manifestations. Some patients require specific treatment in case of auto-immune disorders, inborn errors of metabolism, or genetic disorders (Giannitelli et al. 2018; Consoli et al., 2019). This unit is also the regional referral when electroconvulsive therapy (ECT) is indicated in minors (Consoli et al., 2013).

The last two units are neurobehavioral units for children/adolescents or adults with autism and/or intellectual disability and resistant challenging behaviors (e.g., self-injurious behaviors, aggression, and disruptive behaviors). Treatment plans generally require a combination of symptomatic treatment (e.g., anti-pain drugs), treatment of associated psychiatric disorder (e.g., mood stabilizer for BD), and treatment of associated medical condition (e.g., anti-acid for gastritis). Functional analysis to identify environmental contingencies that contribute to the maintenance of the deviant behaviors enable to implement tailored behavioral interventions. Specific approaches (e.g. compressive garments, therapeutic body wrap, or balneotherapy) centered on sensory-motor dysfunctions can be offered in some cases (Guinchat et al., 2020).

\section{Theoretical frameworks}

We summarize in table 1 the main indications for a hospitalization in a CAPD. The listed is given by frequencies and costs. For the most complex cases, we believe that the theoretical framework should encompass the following perspectives. (i) Developmental: this implies that an early stressor impact development and its outcome will be a function of chronicity, treatment response and resilience. (ii) Multidimensional: this means that all dimensions of development (e.g. language, affect, motor) should be investigated to assess risk factors and tailored treatment (Xavier et al., 2015). (iii) Eco-systemic: this means that a child develops in a system including proximal (e.g. family) and distant (e.g. cultural values) environments. (iv) Multifactorial causality: this means that causal factors are numerous and interact one with another (Cohen, 2010).

This theoretical framework has organizational staff and treatment implications. First, a modern CAPD should be multidisciplinary and include several allied disciplines (e.g., social worker, speech therapist, developmental psychologist, psychoanalyst, occupational therapist). Second, it should be implemented in a large medical setting with close disciplines (e.g., neuro-pediatrics). Third, treatment should be tailored according to clinical, family and social assessments. Forth, therapeutic proposals should be integrative (the opposite being exclusive) and discussed among staff members. They may include all types of psychotherapies, social support and intervention and/or medication. Fifth, some organizational aspects (e.g., weekly meeting with members of all units to discuss complex cases) and teaching hospital care approach (with supervised tutoring) promote high-level of care. Sixth, a modern CAPD should also be opened to cultural interventions (e.g., art therapy) as some youths don't frequent school anymore but are still willing to join 
art/community activities. Seventh, the CAPD should include a school with specialist teachers to facilitate the required long duration stays for some cases and allow educational assessment before individualized projects. Finally, we believe that for complex cases we need to keep being ambitious in terms not only of clinical, but also functional recovery. This means sometimes promoting a life time project with the youth, and challenging the issue of costs with our administrative authorities.

\section{References}

Benarous X, Cravero C, Jakubowicz B, Morales P, lancu C, Pellerin H, Cohen D. (in press). Durée d'hospitalisation en pédopsychiatrie : étude rétrospective des facteurs prédictifs sur deux ans en unité d'adolescents et réflexions générales. Neuropsychiatrie de l'Enfance et de l'Adolescence doi:10.1016/j.neurenf.2020.03.004

Aouidad A, Cohen D, Mirkovic B, Pellerin H, De La Riviere S, Consoli A, Gerardin P, Guile JM (2020) Borderline personality disorder and prior suicide attempts define a severity gradient among hospitalized adolescent suicide attempters. BMC Psychiatry 20:525

Giannitelli M, Cohen D, Jardri R, Bonnot O, Raffin M, Consoli A, Laurent C. (2018) An overview of medical risk factors for childhood psychosis: Implications for research and treatment. Schizophrenia Research 192, 39-49.

Guedj-Bourdiau M-J, Guilé J-M, Garny de la Rivière S, Pace U, Cohen D and Benarous X (2021) Unmet Needs and Classical Pitfalls in the Management of Adolescents With Behavioral Problems in Emergency. Front. Psychiatry 12:527569. doi: 10.3389/fpsyt.2021.527569

Consoli A, Cabal-Berthoumieu S, Raffin M, Thuilleaux D, Poitou C, Coupaye M, Pinto G, Lebbah S, Zahr N, Tauber M, Cohen D, Bonnot O. (2019) Effect of topiramate on eating behaviours in Prader-Willi syndrome: TOPRADER double-blind randomised placebo-controlled study. Translational psychiatry 9:274

Consoli, A, Cohen J, Bodeau N, Guinchat V, Wachtel L, Cohen D. (2013) Electroconvulsive therapy in adolescents with intellectual disability and severe auto/hetero aggressive behaviors: an exploratory study. European Child and Adolescent Psychiatry 22:55-62

Guinchat V, Cravero C, Lefevre-Utile J, Cohen D. (2020) Multidisciplinary treatment plan for challenging behavior in neurodevelopmental disorders. In A. Gallagher, C. Bulteau, D. Cohen, \& J. Michaud (Eds.) Handbook Clinical Neurology (neurodevelopmental and cognitive disabilities) 174: 301-321

Xavier J, Bursztejn C, Stiskin M, Canitano R, Cohen D (2015) Autism spectrum disorders: An historical synthesis and a multidimensional assessment toward a tailored therapeutic program. Research in Autism Spectrum Disorders 18:21-33

Cohen D. (2010) Probabilistic epigenesis: an alternative causal model for conduct disorders in children and adolescents. Neuroscience Bio-behavioral Reviews 34: 119-129. 


\begin{tabular}{|c|c|c|c|}
\hline Indication & Objective of inpatient stay & $\begin{array}{l}\text { Available at } \\
\text { CAPD-PS }\end{array}$ & $\begin{array}{l}\text { Alternatives in the city of } \\
\text { Paris (figure 1) }\end{array}$ \\
\hline $\begin{array}{l}\text { Acute behavioral crisis } \\
\text { including suicide attempt }\end{array}$ & $\begin{array}{l}\text { Brief duration of stay } \\
\text { Separation from family and social network } \\
\text { Individual and family assessment } \\
\text { Organization of outpatient treatment }\end{array}$ & No & $\begin{array}{l}\text { Departments of Pediatrics } \\
\text { Other departments of child } \\
\text { and adolescent psychiatry }\end{array}$ \\
\hline $\begin{array}{l}\text { Severe or repetitive } \\
\text { behavioral manifestations }\end{array}$ & $\begin{array}{l}\text { Longer duration of stay in secure units } \\
\text { Separation from family and social network } \\
\text { Individual and family assessment } \\
\text { Forensic assessment when needed } \\
\text { Organization of outpatient treatment }\end{array}$ & Yes & $\begin{array}{l}\text { Other departments of child } \\
\text { and adolescent psychiatry }\end{array}$ \\
\hline Eating disorder & $\begin{array}{l}\text { Specific inpatient program for eating } \\
\text { disorders }\end{array}$ & No & $\begin{array}{l}\text { Other departments of child } \\
\text { and adolescent psychiatry }\end{array}$ \\
\hline $\begin{array}{l}\text { Rare disease, Catatonia, } \\
\text { Early onset schizophrenia, } \\
\text { early onset bipolar disorder }\end{array}$ & $\begin{array}{l}\text { Individual psychiatric and medical } \\
\text { assessment } \\
\text { Treatment of both psychiatric and } \\
\text { medical conditions }\end{array}$ & Yes & $\begin{array}{l}\text { (Other departments of } \\
\text { child and adolescent } \\
\text { psychiatry) }\end{array}$ \\
\hline $\begin{array}{l}\text { Intractable Self-Injury } \\
\text { Behaviors in patient with } \\
\text { ASD or ID }\end{array}$ & $\begin{array}{l}\text { Individual psychiatric and medical } \\
\text { assessment } \\
\text { Specific inpatient program in so-called } \\
\text { 'neurobehavioral units' }\end{array}$ & Yes & No \\
\hline Exceptional treatment & $\begin{array}{l}\text { ECT } \\
\text { Plasma exchange for autoimmune } \\
\text { encephalitis with psychiatric presentation }\end{array}$ & Yes & No \\
\hline
\end{tabular}

PSL=Pitié-Salpêtrière; ECT=electroconvulsive therapy ; ASD=autism spectrum disorder, ID=intellectual disability 


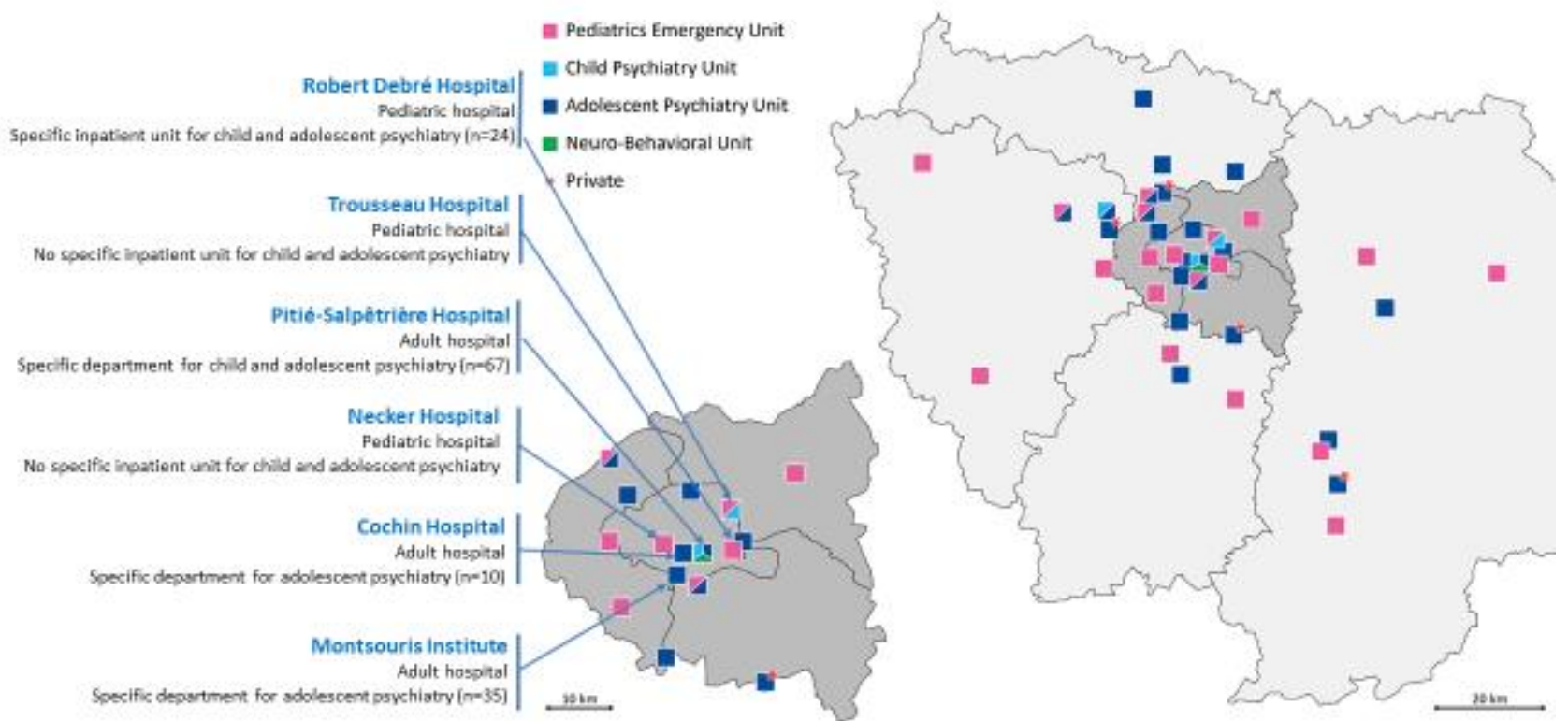

Figure 1. Inpatient units for children and adolescents with psychiatric conditions in the Paris area 